\title{
Functional growth analysis of diploid potato cultivars (Solanum phureja Juz. et Buk.)
}

\section{Análisis funcional de crecimiento de variedades diploides del cultivo de papa (Solanum phureja Juz. et Buk.)}
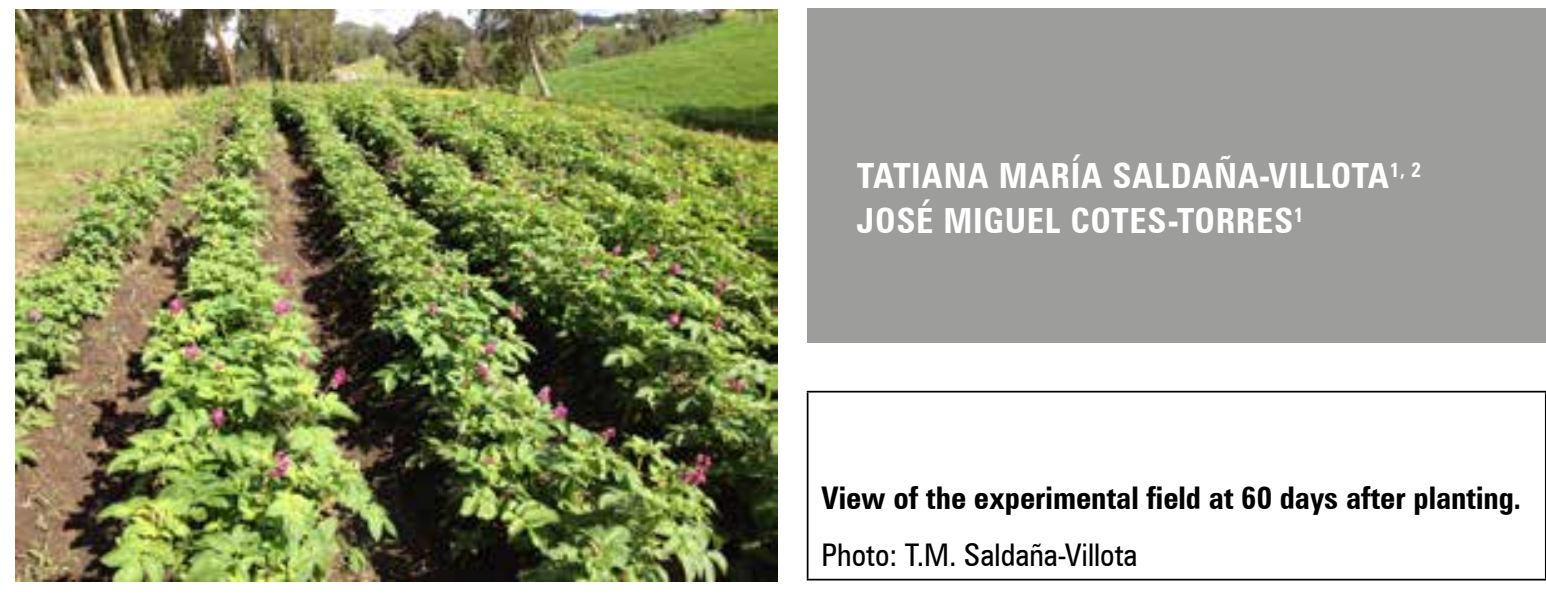

\begin{abstract}
Plant growth analysis has been widely used to study factors that influence plant growth. This analysis uses a set of quantitative methods that describe and analyze the growth of plants and their organs. It uses data from direct measurements (weight, area, volume) and quantifies and analyzes growth using indexes based on models defined by mathematical functions. This study conducted a functional growth analysis of diploid potato cultivars in Colombia. The functional growth analysis of diploid potato cultivars was carried out over three consecutive growing seasons in Medellín, Colombia. A randomized block design was used with two levels of fertilization and five repetitions. The first factor corresponded to the three potato cultivars, and the second factor was two fertilization levels: 260 and $778 \mathrm{~kg}$ of fertilizer per hectare. Samples were taken weekly, and each sample was an entire plant per experiment unit. The dry weight of each organ and the leaf area were measured. These measurements were used to calculate the relative growth rate, leaf area ratio, net assimilation rate, and specific leaf area. The development time was evaluated in accumulated degree-days with threshold temperatures of 2 and $29^{\circ} \mathrm{C}$. The three cultivars recorded their highest net assimilation rate at 1,252 accumulated degree days (ADD), with values of $0.0002565,0.0002021$, and $0.0001778 \mathrm{~g} \mathrm{~cm}^{-2} \mathrm{ADD}^{-1}$ in the 'Latina', 'Guaneña', and 'Colombia' cultivars, respectively. The Latina cultivar stood out in several physiological characteristics, including the fastest developing cultivar. 'Latina' also had the highest total dry mass accumulated in the cycle (271.05 g) and accumulated dry matter in tubers (237 g).
\end{abstract}

Additional keywords: net assimilation rate; relative growth rate; dry matter accumulation; leaf area.

1 Universidad Nacional de Colombia, sede Medellín, Facultad de Ciencias Agrarias, Medellin (Colombia). ORCID Saldaña-Villota, T.M.: 0000-0001-9784-7846; ORCID Cotes-Torres, J.M.: 0000-0002-2211-846X

2 Corresponding autor.tmsaldanav@unal.edu.co 


\section{RESUMEN}

El análisis del crecimiento de las plantas se ha utilizado ampliamente para estudiar los factores que influyen en el crecimiento. Este análisis comprende un conjunto de métodos cuantitativos que describen y analizan el crecimiento de plantas enteras y sus órganos. Utiliza datos de medidas directas (peso, área, volumen), lo que permite cuantificar y analizar el crecimiento, utilizando índices basados en modelos definidos por funciones matemáticas. Este estudio tuvo como objetivo realizar un análisis de crecimiento funcional de cultivares de papa diploides en Colombia. Se llevó a cabo un análisis funcional de crecimiento en tres variedades de papa diploides durante tres ciclos consecutivos en Medellín, Colombia. Se utilizó un diseño de bloques al azar, con dos niveles de fertilización y cinco repeticiones. El primer factor correspondió a las tres variedades de papa diploide y el segundo factor a dos niveles de fertilización: 260 y $778 \mathrm{~kg}$ de fertilizante por hectárea. Se tomaron muestras semanalmente y cada muestra correspondió a una planta completa por unidad experimental. Se midió el peso seco de cada órgano y área foliar que luego, se usaron para calcular la tasa relativa de crecimiento, la relación del área foliar, la tasa de asimilación neta y el área foliar específica. El tiempo de desarrollo se evaluó en grados día acumulados con temperaturas umbrales de 2 y $29^{\circ} \mathrm{C}$. Las tres variedades registraron su mayor tasa de asimilación neta a los 1.252 grados día acumulados (GDA), con valores de $0.0002565,0.0002021$ y $0.0001778 \mathrm{~g} \mathrm{~cm}^{-2} \mathrm{GDA}^{-1}$ para 'Latina', 'Guaneña' y 'Colombia', respectivamente. La variedad Latina se destacó en varias características fisiológicas, y además fue la variedad de desarrollo más rápido. 'Latina' también fue la que tuvo la mayor masa seca total acumulada en el ciclo (271.05 g) y mayor materia seca acumulada en tubérculos $(237 \mathrm{~g})$.

Palabras clave adicionales: tasa de asimilación neta; tasa relativa de crecimiento; acumulación de materia seca; área foliar.

Received for publication: 15-04-2020 Accepted for publication: 23-11-2020

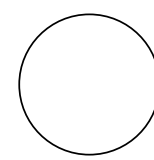

INTRODUCTION

Plant growth is the result of interactions between photosynthesis, respiration, assimilated transport, hydric relationships, and mineral nutrition. It is defined as the irreversible increase in dry matter, volume, length, or area as a consequence of the division, differentiation, and expansion of cells. Development refers to the processes that determine changes in forms and behavior in individuals. Therefore, development involves processes of growth, differentiation and, morphogenesis (Fourcaud et al., 2008; Kutschera, 2019; Lambers et al., 1998; Larcher, 2003; Taiz et al., 2014). These processes are determined by genetics and external factors such as water availability, environmental temperature, and solar radiation (Marenco and Fernandes, 2009; Tekalign and Hammes, 2005).

Plant growth analysis has been widely used to study factors that influence plant growth, such as photoassimilate accumulation over time (Gardner et al., 1985). This analysis uses a set of quantitative methods that describe and analyze the growth of plants and their organs. It uses data from direct measurements (weight, area, volume) that quantify and analyze growth with indexes based on models defined by mathematical functions (Hunt, 1982, 2003).

In the past, growth analyses used measurements taken over a long period of time using a large number of plants (Hendrik, 1989; Hunt, 1982). Then, the growth analysis approach was modified to use samples in a short period of time with a small number of plants; this approach is used to this day because the concept of growth has not changed (Oliveira et al., 2016). The functional analysis provides mathematical functions that describe plant growth (Hunt, 2003) using information obtained from dry weight and leaf area. Thus, these mathematical functions can be used to estimate the relative growth rate (RGR), crop growth rate (CGR), leaf area ratio (LAR), net assimilation rate (NAR), specific leaf area (SLA), leaf area index (LAI) and leaf area duration (LAD) (Hunt, 1982), which explain plant growth.

Some studies have described the growth and development of potato cultivars in Latin America. Santos (2010) evaluated diploid potato cultivars (Colombia, Latina, Guaneña, and Galeras) in two locations 
in Bogota. They found that 'Guaneña' reached the highest RGR at the beginning of the crop cycle and the highest NAR 35 days after emergence. Gaitán et al. (2013) studied tetraploid potato cultivars (Zipa, Unica, Monserrate, and Morita). They found the maximum NAR values at 17 weeks after emergence, with an RGR that continuously decreased from planting until harvest, except for the Morita cultivar, which increased this physiological parameter until the $12^{\text {th }}$ week, after which it decreased until harvest.

In Brazil, De Oliveira et al. (2000) studied a tetraploid cultivar (Aracy) with different irrigation levels. They found that RGR and NAR values decreased over time from planting to some days before harvest, when a small increase occurred. In Mexico, Aguilar et al. (2006) carried out a growth analysis of tetraploid cultivars (Milagros and Alpha) and adjusted the dry weights to polynomial models to mathematically describe the growth of the cultivars. Borrego et al. (2000) evaluated the tetraploid potato cultivars Snowden, Norteña, Mondial, Atlantic, Alpha, and Russett Burbank to determine differences between genotypes with growth analysis and reported that the NAR index is the most useful index for highlighting the advantages of a cultivar over others.

Condori et al. (2008) carried out an agrophysiological characterization of tuber-forming plants, including the tetraploid potato cultivars Luki, Alpha, and Waycha, and found no differences in the NAR and RGR values. They also noticed more efficient than other species, such as oca (Oxalis tuberosa), isaño (Tropaeolum tuberosum), and papalisa (Ullucus tuberosus).

The growth dynamic of diploid potato genotypes obtained with plant breeding has not been studied, so the present study was carried out. Because growth analysis is a useful tool for comparing cultivars in terms of physiological behavior, this study carried out a functional growth analysis of diploid potato cultivars in Colombia.

\section{MATERIALS AND METHODS}

Three consecutive growing seasons of the diploid potato cultivars Colombia, Latina, and Guaneña were evaluated in Medellin (Colombia). The experimental field was established in an area of $510 \mathrm{~m}^{2}$. The distance between plants was $0.30 \mathrm{~m}$, and the distance between rows was $0.90 \mathrm{~m}$. Thus, the plant density was 37,037 plants/ha. Detailed information about the experiment is given in table 1. According to the ecological conditions, the area was a lower tropical moist forest mountain life zone (Holdridge, 1967).

Diploid potato cultivars belong to the Phureja group. S. phureja cultivars are characterized by their short life cycle, short day adaptation, low or non-existent tuber dormancy, and diploid nature $(2 \mathrm{n}=2 \mathrm{x}=24)$. $S$. phureja has a range of landraces widely grown in the Andes, from western Venezuela to central Bolivia, excellent culinary properties, and other traits, such as tolerance to Phytophthora infestans, making it very useful for developing modern cultivars (Machida-Hirano, 2015; Ovchinnikova et al., 2011).

\section{Experiment design}

A randomized block design with a factorial arrangement $(3 \times 2)$ was used during each growing season. The first factor corresponded to the three diploid potato cultivars, and the second factor was two fertilization levels: 7 and $21 \mathrm{~g}$ per planting site, representing 260 and $778 \mathrm{~kg} \mathrm{ha}^{-1}$ of fertilizer. The fertilizer grade was 10-20-20-5 (N-P-K-S), and the high dose corresponded to the dose frequently used by farmers. The fertilizer was applied at sampling around the tuber seed and $20 \mathrm{~d}$ after emergence around the stem.

One plant was sampled weekly from each experiment unit. The evaluated variables included dry weights and total leaf area (TLA) with a Leaf Area Meter (LICOR 3100). Each plant was dissected to measure the dry matter, separating each organ and packing them in paper bags. The plants were dried at $80^{\circ} \mathrm{C}$ until constant dry weight was obtained, and separated into leaves (DLW), stems (DSW), roots (DRW), stolons (DSTW), tubers (DTBW), flowers (DFW), fruits (DFRW) and total dry weight (TDW).

The developmental time was measured in terms of thermal time in accumulated degree-days (ADD). The methods followed to compute the thermal time were proposed by Rodríguez et al. (2012) with a threshold temperature of 2 and $29^{\circ} \mathrm{C}$ (Struik, 2007) the focus is on the temperature range between the base temperature and the ceiling temperature as experienced by a plant in the field or in facilities of climatic control. Temperatures at which the plant can no longer function or is even directly damaged (for example, temperature at which the plant is killed by frost or scorched by heat. The thermal time was computed based on information obtained with a 
Table 1. Detailed information about the experiments, location, treatments, measured growth variables, and weather variables.

\begin{tabular}{|c|c|c|c|}
\hline \multirow{2}{*}{ Parameter } & \multicolumn{3}{|c|}{ Field experiments } \\
\hline & 1 & 2 & 3 \\
\hline Location in Colombia & Medellin & Medellin & Medellin \\
\hline Planting date & 2011-08-31 & 2012-01-05 & 2012-05-15 \\
\hline Harvest date & 2011-12-18 & 2012-04-25 & 2012-09-01 \\
\hline Latitude & \multicolumn{3}{|c|}{6.20810} \\
\hline Longitude & \multicolumn{3}{|c|}{-75.49950} \\
\hline Altitude (m a.s.l.) & \multicolumn{3}{|c|}{2,575} \\
\hline Cultivars & \multicolumn{3}{|c|}{$\begin{array}{c}\text { Colombia } \\
\text { Latina } \\
\text { Guaneña }\end{array}$} \\
\hline Treatments & \multicolumn{3}{|c|}{$\begin{array}{l}\text { A. } 778 \mathrm{~kg} \mathrm{ha}^{-1} \\
\text { B. } 260 \mathrm{~kg} \mathrm{ha}^{-1}\end{array}$} \\
\hline Planting density (plants/ha) & \multicolumn{3}{|c|}{37,037} \\
\hline Number of treatments & \multicolumn{3}{|c|}{6} \\
\hline Repetitions & \multicolumn{3}{|c|}{5} \\
\hline In-season sampling & 11 & 12 & 12 \\
\hline Measured variables ${ }^{a}$ & \multicolumn{3}{|c|}{ RDW, TBDW, SDW, LDW, FLDW, FRDW } \\
\hline Soil textureb & LS & SL & LS \\
\hline Cumulative rainfall during the growing season (mm) & 1,096 & 767 & 434 \\
\hline Cumulative radiation during the growing season $\left(\mathrm{MJ} \mathrm{m}^{-2}\right)$ & 1,771 & 1,973 & 2,638 \\
\hline Mean temperature during the growing season $\left({ }^{\circ} \mathrm{C}\right)$ & 14.4 & 14.6 & 15.4 \\
\hline
\end{tabular}

a RDW: root dry weight (kg ha-1). TBDW: tuber dry weight $\left(\mathrm{kg} \mathrm{ha}^{-1}\right)$. SDW: stem dry weight (kg ha-1). LDW: leaf dry weight (kg ha-1). FRDW: fruit dry weight (kg ha-1). FLDW: flower dry weight $\left(\mathrm{kg} \mathrm{ha}^{-1}\right)$.

${ }^{\mathrm{b}}$ LM: loamy sand. SL: sandy loam.

WatchDog 2900ET weather station, which recorded the temperature every $15 \mathrm{~min}$.

\section{Statistical analysis}

The Incomplete Gamma distribution model was used (Wood, 1967) (Eq. 1) because it is consistent with the modeling theory of crops based on models with delays (Gutierrez, 1996; Manetsch, 1976; Rodríguez, et al., 2011; Vansickle, 1977).

$$
y=\alpha x^{\beta} e^{-\gamma x}
$$

This model was linearized with Eq. 2:

$$
\ln (\boldsymbol{y})=\ln \alpha+\beta \ln (\boldsymbol{x})-\gamma \boldsymbol{x}
$$

A multilevel regression model with variable regression coefficients (Gelman and Hill, 2007) was considered from Wood's model for each treatment and trial to analyze the data, generating the following mixed model (Sorensen and Gianola, 2002) (Eq. 3):

$\ln (\boldsymbol{y})=1_{\mathrm{n}} \alpha+\ln (\boldsymbol{t}) \beta+\boldsymbol{t} \gamma+Z_{1} \boldsymbol{a}+\boldsymbol{Z}_{2} \boldsymbol{b}+\boldsymbol{Z}_{3} \boldsymbol{c}+\boldsymbol{Z}_{4} \boldsymbol{u}+\varepsilon$

where, $a, b$, and $g$ are the average regression coefficient vectors for each treatment; $a, b$ and $c$ are the deviation vectors for each trial of average regression coefficients; $u$ is the vector of coefficients of error resulting from the effect of blocks within sampling and trial; $\varepsilon$ is the vector of residual effects of the error; $1_{n}$ is a vector of each size $n ; \ln (t)$ is a vector with the logarithm of the developmental time; $t$ is a vector with the thermal time; and $Z_{1}, Z_{2}, Z_{3}$, and $Z_{4}$ are the incidence matrices of the random effects $a, b, c$ and $u$, respectively. It was assumed that the random effects and the residual error followed a normal distribution with zero mean and variance $\sigma_{a}^{2}, \sigma_{b}^{2}, \sigma_{c}^{2}$, $\sigma_{u}^{2}$, and $\sigma_{\varepsilon}^{2}$ (Searle et al., 1992). Finally, $y$ is the vector with the 
response variable to consider, that is, LA, DTW, DLW, DSW, DRW, DSTW, DTBW, DFW, and DFRW.

Since the measurements of the variables were taken with the same individual, a multi-characteristic model was considered (Eq. 4):

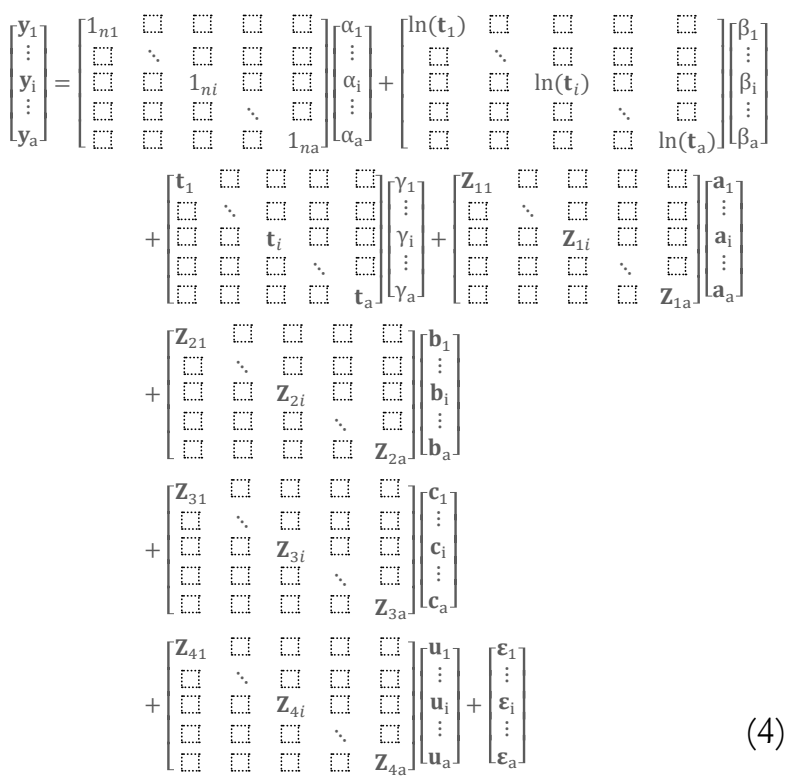

It was assumed that vectors $a, b, c, u$ and $e$ were normally distributed with zero mean and variance $R_{a}$ $\otimes I_{a}, R_{b} \otimes I_{a}, R_{c} \otimes I_{a}, R_{u} \otimes I_{a}$ and $R_{\varepsilon} \otimes I_{a}, R_{(\cdot)}$, respectively, with the covariance matrix , as expressed with Eq. 5 (Sorensen and Gianola, 2002):

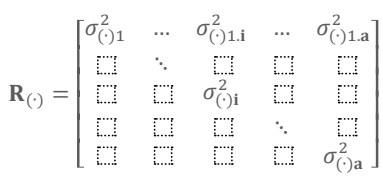

where, I is an identity of a size, a is the number of variables to evaluate, $n$ indicates the number of data of each variable $i$, also $i=\{1, \ldots, a\}$ and $\otimes$ is the Kronecker product.

The Bayesian estimation methodology for the previous model was used with the Gibbs algorithm, generating a Markov chain with a length of one million for each parameter. One sample was selected from each group of ten samples, and the first 10,000 were considered the burn-in period, which was removed. The MCMCglmm package (Hadfield 2010) from the $R$ statistical environment ( $R$ Core Team, 2020) was used. To establish the existence of significant differences between the curves obtained for the leaf area and dry matter accumulation, a comparison of the Highest Posterior Density Interval was made of the fitted model for each cultivar at each level of fertilization. Each graph determined the statistical differences using 0.90 Highest Posterior Density Interval curves calculated with the CODA package (Plummer et al. 2006), and with the Bayes estimator the average marginal posterior distribution was obtained, this minimized the quadratic loss function.

The total dry weight (TDW) was determined (Eq. 6). Markov chain samples were used to obtain the original variables (LA, DTW, DLW, DSW, DRW, DSTW, DTBW, DFW, DFRW) and the physiological parameters relative growth rate (RGR) (Eq. 8), net assimilation rate (NAR) (Eq. 9), leaf area ratio (LAR) (Eq. 10), specific leaf area (SLA) (Eq. 11) and fresh weight ratio (FWR) (Eq. 12).

$$
\begin{gathered}
\text { TDW }=\mathrm{w}=\text { DRW }+ \text { DSTW }+ \text { DSW }+ \text { DLW }+ \text { DFW }+ \text { DFRW }+ \text { DTBW } \\
\frac{d w}{d t}=\frac{d_{\text {DWR }}}{d t}+\frac{d_{\text {DWST }}}{d t}+\frac{d_{\text {DWS }}}{d t}+\frac{d_{\text {DWL }}}{d t}+\frac{d_{\text {DWF }}}{d t}+\frac{d_{\text {DWFR }}}{d t}+\frac{d_{\text {DWTB }}}{d t} \\
\text { RGR }=\frac{1}{W} \times \frac{d w}{d t} \\
\text { NAR }=\frac{1}{\text { LA }} \times \frac{d w}{d t} \\
\text { LAR }=\frac{\text { LA }}{W} \\
\text { SLA }=\frac{\text { LA }}{\text { DWL }} \\
F W R=\frac{\text { DWL }}{W}
\end{gathered}
$$

\section{RESULTS AND DISCUSSION}

\section{Leaf area accumulation}

The 'Guaneña' cultivar had the greatest leaf area during the cycle with both fertilization doses. At 121.30 $\mathrm{ADD}$ in the low dose of fertilizer, it reached 4,827.69 $\mathrm{cm}^{2}$, and in high dose, at $947.83 \mathrm{ADD}$ achieved the maximum value corresponding to $6,085.97 \mathrm{~cm}^{2}$. Most nutrition conditions allowed the plants to develop a higher number of leaves in a shorter time (Fig. 1).

The Latina and Colombia cultivars reached their highest leaf area values between 812.64 and 880.23 $\mathrm{ADD}$ with the highest fertilizer dose, with values of 


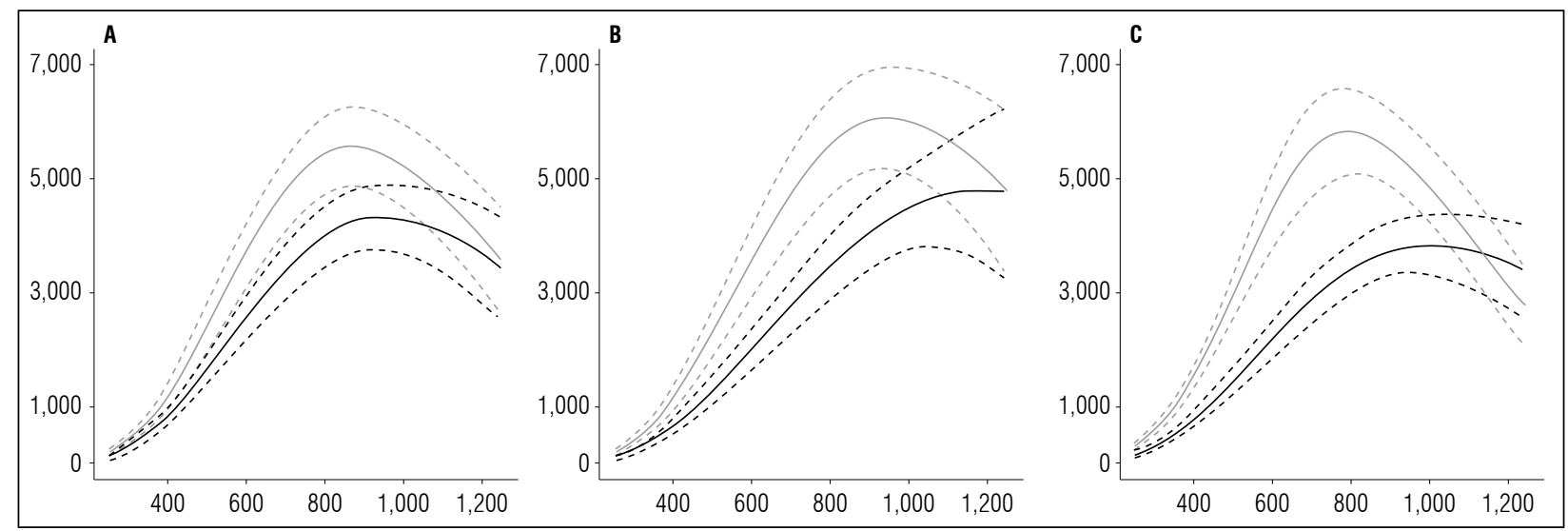

Figure 1. Leaf area growth curve in diploid potato cultivars (Solanum phureja Juz. et Buk.). The y-axis shows leaf area (LA) in $\mathrm{cm}^{2}$. The $\mathrm{x}$-axis shows the thermal time in accumulated degree-days (ADD). The black line indicates the dose of 260 $\mathrm{kg} \mathrm{ha}^{-1}$, and the gray line indicates the dose of $778 \mathrm{~kg} \mathrm{ha}^{-1}$. The dotted lines of each color indicate the Highest Posterior Density Intervals of 0.90. A, 'Colombia'; B. 'Guaneña'; C, 'Latina'.
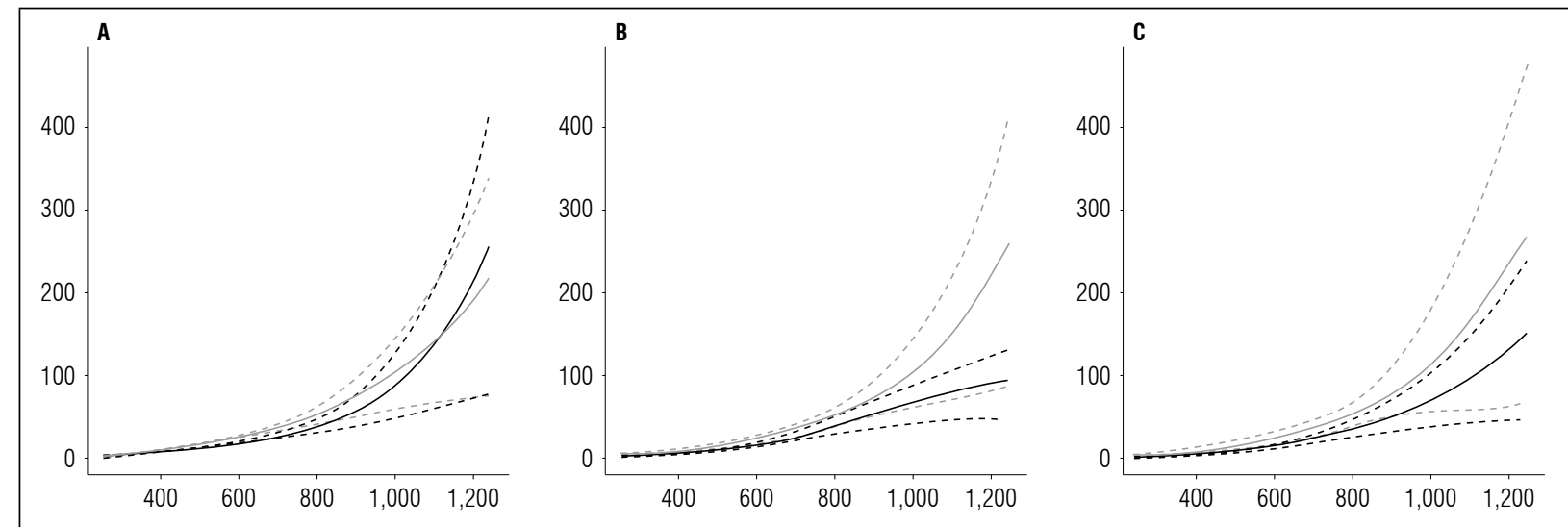

Figure 2. Total dry weight accumulated in diploid potato cultivars (Solanum phureja Juz. et Buk.). The y-axis shows the total dry weight (TDW) in $g$. The $x$-axis shows the thermal time in accumulated degree-days (ADD). The black line indicates the dose of $260 \mathrm{~kg} \mathrm{ha}^{-1}$, and the gray line indicates the dose of $778 \mathrm{~kg} \mathrm{ha}^{-1}$. The dotted lines of each color indicate the Highest Posterior Density Intervals of 0.90. A, 'Colombia'; B 'Guaneña'; C, 'Latina'.

$5,838.80$ and $5,567.65 \mathrm{~cm}^{2}$, respectively. Although these cultivars peaked before 'Guaneña', the values differ by almost $1,000 \mathrm{~cm}^{2}$, which, in terms of production, can generate differences in the ability of plants to capture the incident radiation and increase the production of assimilates that are reflected at the end of a cycle with increased yield.

The leaf area obtained in this study for the Colombia cultivar was lower than the value reported by Cabezas and Corchuelo (2005), who evaluated the same cultivar at three locations in Bogota, Colombia, under the effect of crop planting densities. At a 4.14 sites/m density, which is the density closest to the one used in this experiment, they obtained an average value for the three locations of $6,909.56 \mathrm{~cm}^{2} 90$ $\mathrm{d}$ after planting, when tuber maturation occurred. Santos (2010) found significant differences. The author reported maximum leaf area values at the end of the cycle that varied with the cultivar from 12,000 to $20,000 \mathrm{~cm}^{2} /$ plant. These differences may have been due, in the first instance, to the highly contrasting ecological conditions under which the experiments were carried out and also the number of plants per unit area.

The curves that describe the leaf area behavior in this research showed an increase in the leaves to 


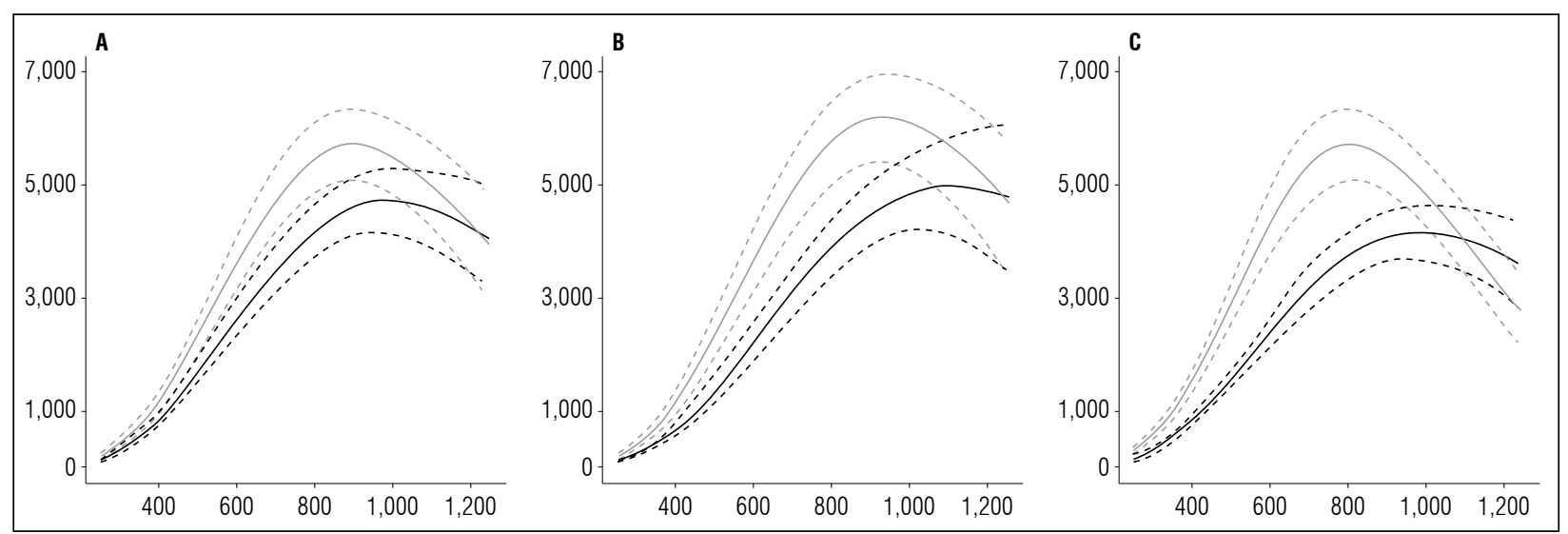

Figure 3. Leaf growth curves in diploid potato cultivars (Solanum phureja Juz. et Buk.) in terms of dry weight. The y-axis shows the leaf dry weight (LDW) in g. The x-axis shows the thermal time in accumulated degree-days (ADD). The black line indicates the dose of $260 \mathrm{~kg} \mathrm{ha}^{-1}$, and the gray line indicates the dose of $778 \mathrm{~kg} \mathrm{ha}^{-1}$. The dotted lines of each color indicate the Highest Posterior Density Intervals of 0.90. A, 'Colombia'; B, 'Guaneña'; C, 'Latina'.

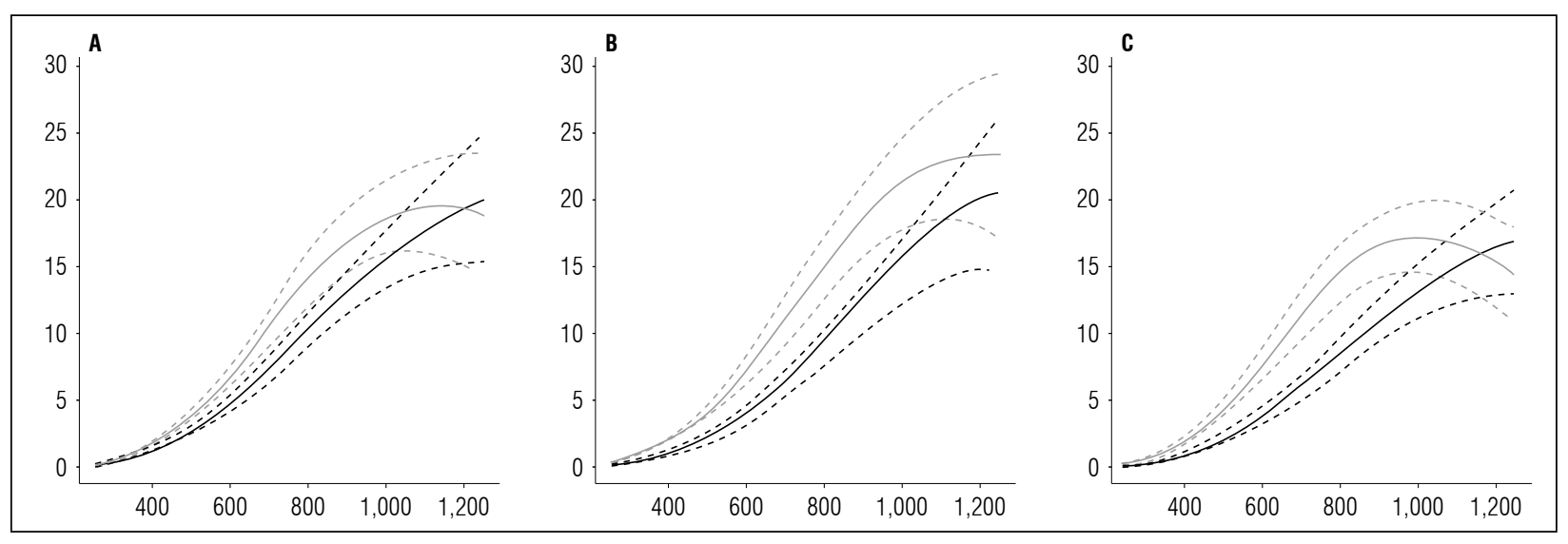

Figure 4. Stem growth curves of diploid potato cultivars (Solanum phureja Juz. et Buk.) in terms of dry weight. The y-axis shows the stem dry weight (SDW) in $g$. The $x$-axis shows the thermal time in accumulated degree-days (ADD). The black line indicates the dose of $260 \mathrm{~kg} \mathrm{ha}^{-1}$, and the gray line indicates the dose of $778 \mathrm{~kg} \mathrm{ha}^{-1}$. The dotted lines of each color indicate the Highest Posterior Density Intervals of 0.90. A, 'Colombia'; B, 'Guaneña'; C, 'Latina'.

maximum formation. This condition decreased as the harvest approached and leaves were lost through natural causes because of the translocation of assimilates to the tubers and cultural practices (Montoya et al., 2016) at 100,80 and $60 \%$ of the water requirement.

\section{Dry matter accumulation}

The accumulation of dry matter was notably influenced by biomass accumulation in the tubers, which, after $800 \mathrm{ADD}$, increased substantially until the end of the cycle, while the other organs stabilized their dry matter accumulation. The biomass accumulation in the leaves and flowers decreased when the tuber filling started (Fig. 2).

All cultivars reached the greatest accumulation of dry matter at 1,252 $\mathrm{ADD}$, regardless of the fertilization dose. The maximum value was reached with 'Latina' (271.05 g), followed by 'Guaneña' (260.19 g) and 'Colombia' (221.07 g) with the highest fertilization dose.

The highest dry matter accumulation in the leaves was observed in 'Guaneña' (20.93 g) at $930.93 \mathrm{ADD}$ with the highest fertilizer dose, followed by 'Latina' and 'Colombia', which reached a maximum of 19.21 $g$ at 812.64 and $897.13 \mathrm{ADD}$, respectively. Guaneña 

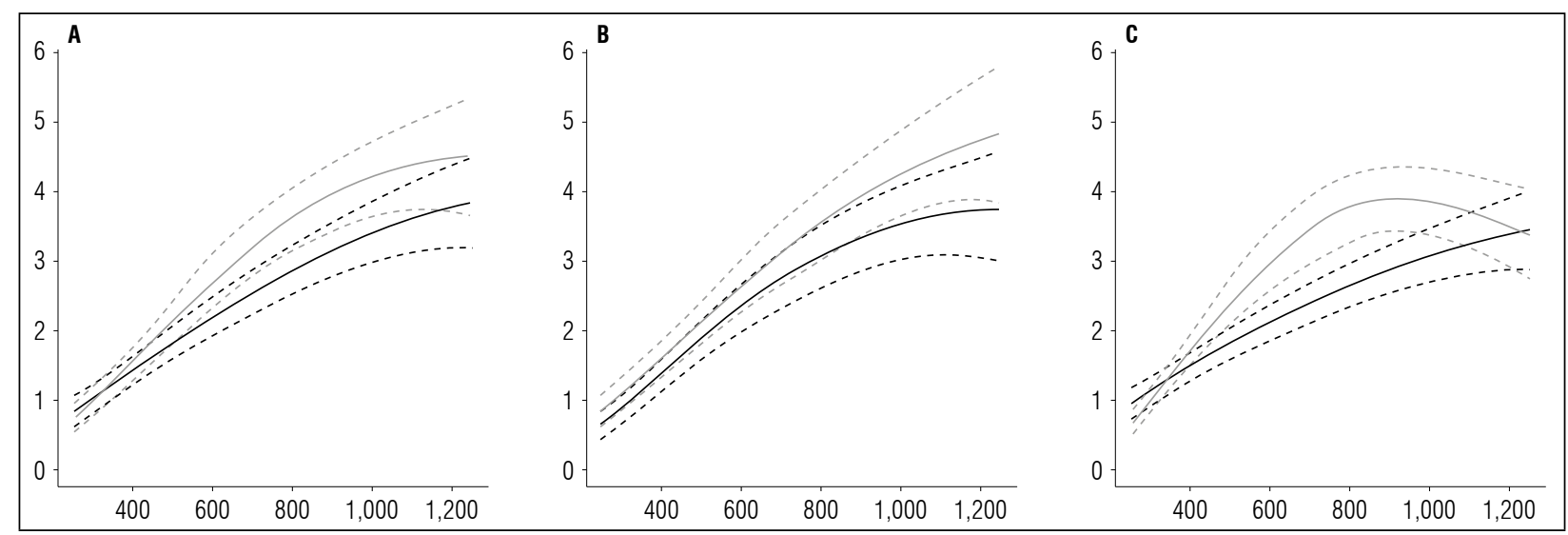

Figure 5. Root growth curves in diploid potato cultivars (Solanum phureja Juz. et Buk.) in terms of dry weight. The y-axis shows the root dry weight (RDW) in g. The x-axis shows the thermal time in accumulated degree-days (ADD). The black line indicates the dose of $260 \mathrm{~kg} \mathrm{ha}^{-1}$, and the gray line indicates the dose of $778 \mathrm{~kg} \mathrm{ha}^{-1}$. The dotted lines of each color indicate the Highest Posterior Density Intervals of 0.90. A, 'Colombia'; B, 'Guaneña'; C, 'Latina'.

was also the cultivar that accumulated the most dry matter in the leaves with the lowest fertilizer dose $(16.77 \mathrm{~g})$ at $1,116.81 \mathrm{ADD}$. When nutritional conditions are lower, the accumulation of dry matter is lower, and plants need more time to accumulate biomass. Less dry matter in leaves results in a smaller leaf area and lower production of photoassimilates for translocation to the organ of economic interest (Fig. 3).

Unlike Solanum tuberosum L., which has a senescence period, diploid potato cultivars are kept alive until harvest. Therefore, at the end of the cycle, the accumulation curve increased and did not plateau like the results of Gaitán et al. (2013), who indicated that, at about 18 weeks after planting, the highest peak of total dry matter accumulation was reached in all four evaluated cultivars; afterwards, the buildup decreased until the end of the cycle and, in some cases, lost half the weight. Santos (2010) conducted a study at a lower altitude (2,572 $\mathrm{m}$ a.s.1.), and 'Guaneña' stood out because of its higher biomass accumulation in leaves. However, the maximum values obtained in this study were lower than the values obtained by this author, who obtained $53.8 \mathrm{~g}$ at $77 \mathrm{~d}$ after emergence.

As in the leaf dry matter accumulation curve, 'Guaneña' had the maximum value for stems (23.49 g) at $1218 \mathrm{ADD}$ with the highest fertilization dose, followed by 'Colombia' and 'Latina', which reached their maximum dry matter accumulation in stems (19.51 and $17.16 \mathrm{~g})$ at $1,133.71$ and $1,015.42 \mathrm{ADD}$, respectively. The three cultivars with the lowest fertilization dose reached maximum dry matter accumulation in stems at 1,252 ADD; 'Guaneña' had the highest value ( $20.47 \mathrm{~g}$ ), followed by 'Colombia' (20 g) and 'Latina' (17.16 g) (Fig. 4).

Santos (2010) reported higher values for the Guaneña cultivar than this study. This author reported a value of $72 \mathrm{~g}$ at $77 \mathrm{~d}$ after emergence, close to the peak for the cultivar Morita reported by Gaitán et al. (2013). Furthermore, Santos (2010) reported the highest dry matter accumulation in tubers for 'Galeras' (177.8 g) at $77 \mathrm{~d}$ after planting, followed by 'Latina' (153.3 g), 'Guaneña' (142.1 g), and 'Colombia' with $100 \mathrm{~g}$.

The root system of potato plants is sparse and weak (Huamán, 1986), as evidenced in the dry matter accumulation in this organ by the cultivars in this study. The maximum accumulation achieved was $4.85 \mathrm{~g}$ in cultivar Guaneña. The maximum values accumulated in the Colombia and Latina cultivars were 4.53 and $3.92 \mathrm{~g}$, respectively. All three materials reached these values at the end of the cycle at 1,252 ADD (Fig. 5).

The stolon dry matter accumulation curve looked similar to the leaf curve, where it reached a peak of maximum accumulation and rate decreased to the end of the cycle because the tubers at that time have the largest filling capacity. The maximum dry matter accumulation was in 'Colombia' with $1.56 \mathrm{~g}$ at 964.72 ADD with the highest fertilizer dose per hectare, followed by 'Latina' and 'Guaneña' with $1.27 \mathrm{~g}$ and 0.94 g, respectively (Fig. 6). 

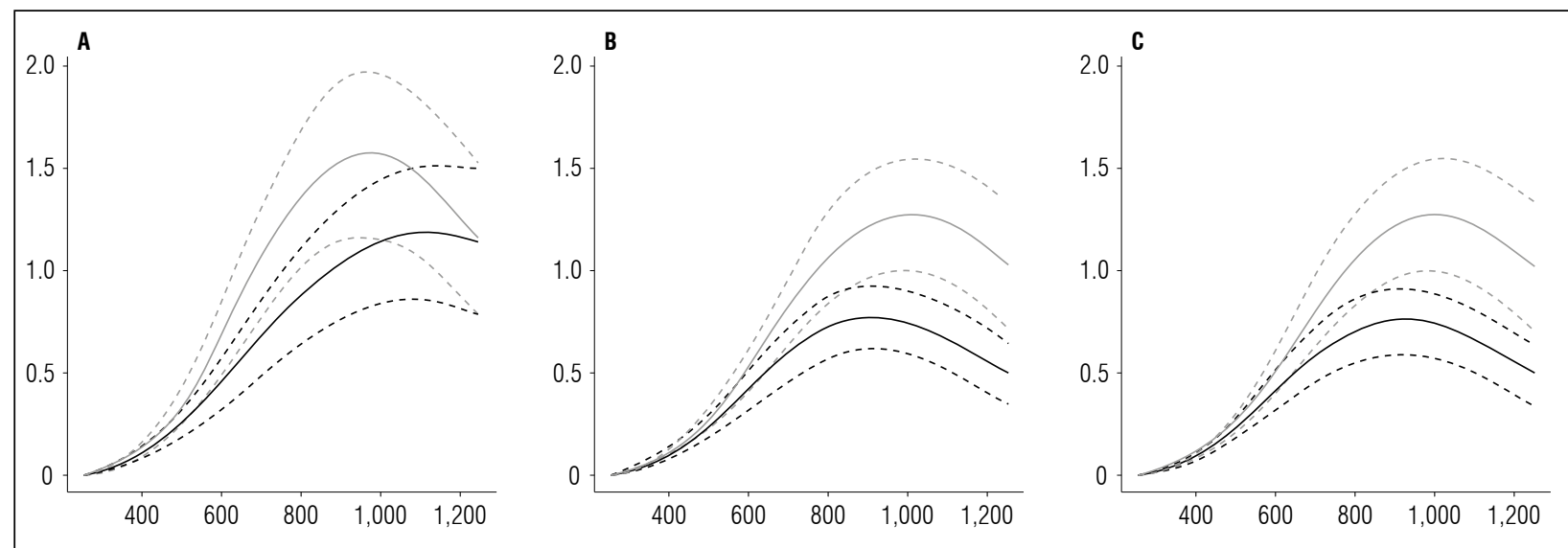

Figure 6. Stolon growth curves in diploid potato cultivars (Solanum phureja Juz. et Buk.) in terms of dry weight. The y-axis shows the stolon dry weight (STDW) in $\mathrm{g}$. The x-axis shows the thermal time in accumulated degree-days ADD. The black line indicates the dose of $260 \mathrm{~kg} \mathrm{ha}^{-1}$, and the gray line indicates the dose of $778 \mathrm{~kg} \mathrm{ha}^{-1}$. The dotted lines of each color indicate the Highest Posterior Density Intervals of 0.90. A, 'Colombia'; B, 'Guaneña'; C, 'Latina'.

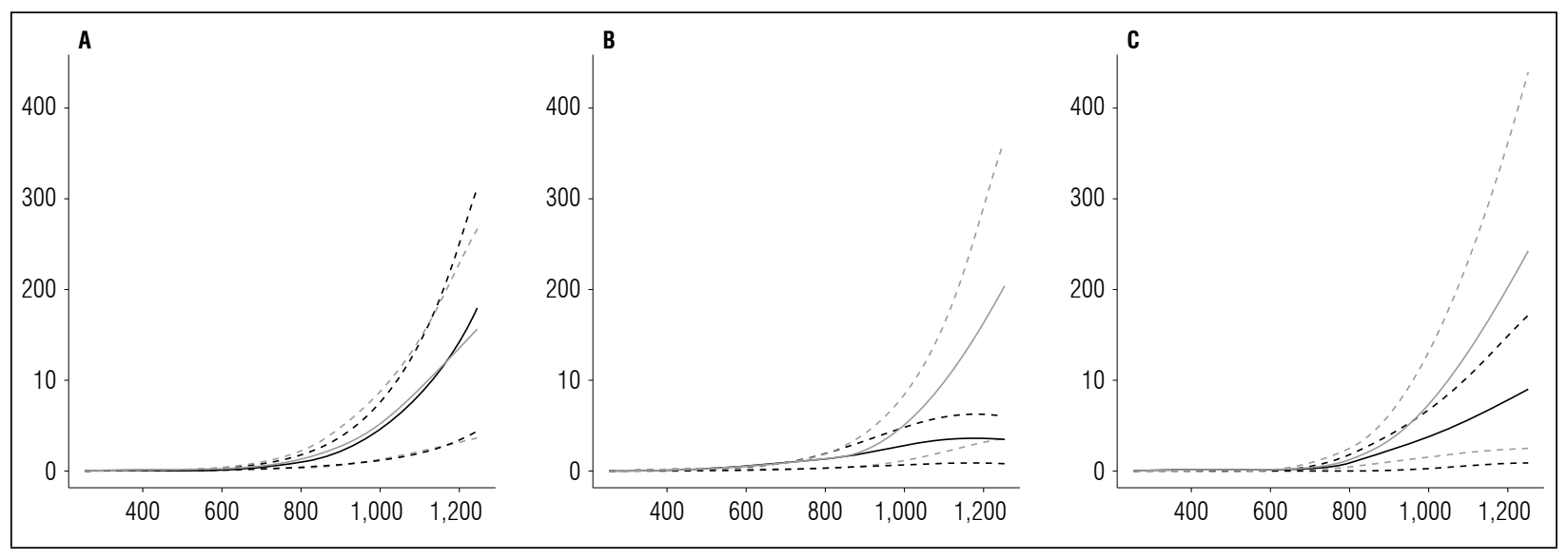

Figure 7. Tuber growth curves in potato cultivars (Solanum phureja Juz. et Buk.) in terms of dry weight. The y-axis shows tuber dry weight (TDW) in $g$. The $x$-axis shows the thermal time in accumulated degree-days (ADD). The black line indicates the dose of $260 \mathrm{~kg} \mathrm{ha}^{-1}$, and the gray line indicates the dose of $778 \mathrm{~kg} \mathrm{ha}^{-1}$. The dotted lines of each color indicate the Highest Posterior Density Intervals of 0.90. A, 'Colombia'; B, 'Guaneña'; C, 'Latina'.

Tubers are modified stems and are the storage organ in potato plants (Huamán, 1986). Therefore, the highest dry matter accumulation occurs in this organ, and it defines the final crop production. The three cultivars reached their highest dry matter accumulation in tubers at 1,252 ADD, where 'Latina' stood out with the highest value $(237 \mathrm{~g})$, followed by 'Guaneña' (201.22 g) and 'Colombia' (155.37 g) with the highest fertilizer dose. With the lowest fertilization dose, shallow maximum accumulation occurred in the Guaneña cultivar ( $35.21 \mathrm{~g}$ ), which could mean that proper management of soil nutrients is required for this cultivar to achieve optimal tuber filling and good production (Fig. 7).

\section{Relative growth rate and net assimilation rate}

'Latina' presented a more accelerated development with the highest fertilization dose. Its RGR reached 0 value at 1,099.9 ADD, followed by 'Colombia' at 1,150.61 ADD. The cultivar Guaneña registered the lowest $\mathrm{RGR}$ value $\left(0.00059 \mathrm{~g} \mathrm{~g}^{-1} \mathrm{ADD}^{-1}\right)$ at $1,252 \mathrm{ADD}$, at the end of the cycle. The fact that 'Guaneña' did not reach 0 during the crop cycle indicated that the plant would have continued growing if the crop had lasted longer. The cultivar 'Guaneña' showed greater precocity with the lowest fertilization, reaching the 0 value for RGR at 1,201.3 ADD. The cultivars Colombia and Latina reached minimum RGR values at 

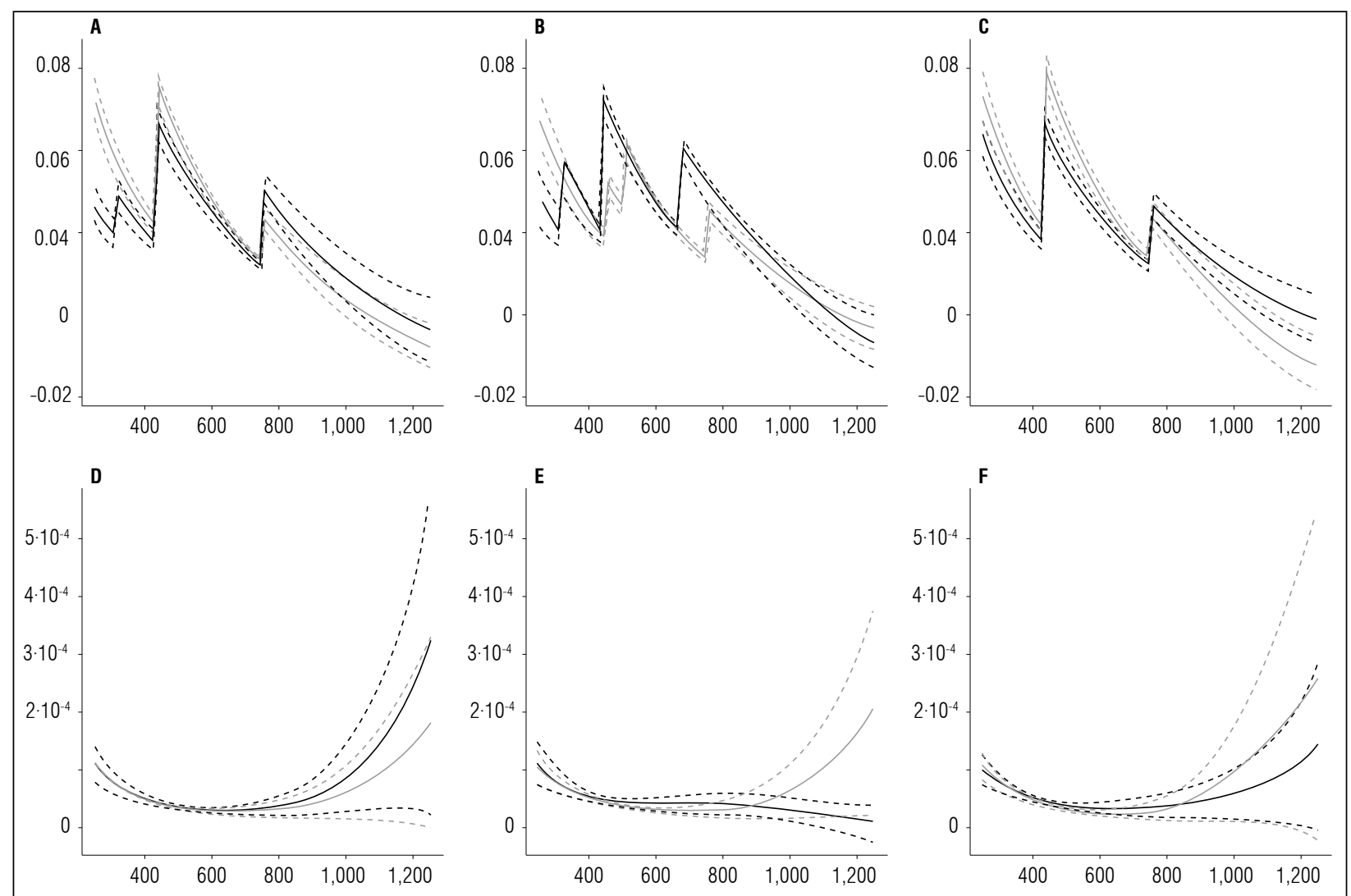

Figure 8. Relative Growth Rate (RGR) and Net Assimilation Rate (NAR) in potato cultivars (Solanum phureja Juz. et Buk.). The $y$-axis in figures $A, B$ and $C$ shows the $R G R$ in $\mathrm{g} \mathrm{g}^{-1} A D D^{-1}$ and in figures $D, E$ and $F$ shows the NAR in $\mathrm{g} \mathrm{cm}^{-2} A D D^{-1}$. The $x$-axis shows the thermal time in accumulated degree-days (ADD). The black line indicates the dose of $260 \mathrm{~kg} \mathrm{ha}^{-1}$, and the gray line indicates the dose of $778 \mathrm{~kg} \mathrm{ha}^{-1}$. The dotted lines of each color indicate the Highest Posterior Density Intervals of 0.90. A, RGR 'Colombia'; B, RGR 'Guaneña'; C, RGR 'Latina'; D, NAR 'Colombia'; E, NAR 'Guaneña'; F, NAR 'Latina'.

$1,252 \mathrm{ADD}, 0.000054$ and $0.0033 \mathrm{~g} \mathrm{~g}^{-1} \mathrm{ADD}^{-1}$, respectively, indicating that the plants were still growing at harvest (Fig. 8).

The behavior of RGR generally depends on the time of development of each organ. The peaks occurred at crucial moments, such as between 400 and $520 \mathrm{ADD}$, when the tuber initiation was recorded. Lower value peaks also take place later in the cycle, with fruit filling.

Hunt (2002) stated that RGR is a physiological parameter that can measure how fast plants grow. The Latina cultivar was more efficient with the highest fertilization dose at producing dry mass at 440.88 $\mathrm{ADD}$, with a value of $0.078 \mathrm{~g} \mathrm{~g}^{-1} \mathrm{ADD}^{-1}$. 'Colombia' had a rate of increase for dry weight that was close to the rate in 'Latina' $\left(0.073 \mathrm{~g} \mathrm{~g}^{-1} \mathrm{ADD}^{-1}\right)$, while 'Guaneña' was faster at $255 \mathrm{ADD}$, with a dry matter increase of $0.063 \mathrm{~g} \mathrm{~g}^{-1} \mathrm{ADD}^{-1}$. The Guaneña cultivar only reached its maximum RGR at the beginning of the growing season with the highest fertilization dose. However, this cultivar, with the lowest fertilization dose, reached the highest rate of increase in dry weight at $440.88 \mathrm{ADD}$, with a value of $0.069 \mathrm{~g}$ $\mathrm{g}^{-1} \mathrm{ADD}^{-1}$, followed by 'Colombia' and 'Latina' (0.062 and $\left.0.061 \mathrm{~g} \mathrm{~g}^{-1} \mathrm{ADD}^{-1}\right)$.

In all the cases, the RGR reached the lowest value when the NAR reached the highest values at 1,252 $\mathrm{ADD}$, except for the Guaneña cultivar with the lowest fertilization dose, where the lowest RGR (-0.0034 $\left.\mathrm{g} \mathrm{g}^{-1} \mathrm{ADD}^{-1}\right)$ was achieved with the lowest NAR $\left(0.000011 \mathrm{~g} \mathrm{~cm}^{-2} \mathrm{ADD}^{-1}\right)$ at $1,252 \mathrm{ADD}$.

With the lowest fertilizer dose, the Colombia cultivar had the highest NAR value $\left(0.00032 \mathrm{~g} \mathrm{~cm}^{-2} \mathrm{ADD}^{-1}\right)$, followed by 'Latina' and 'Guaneña' with values of 
0.00014 and $0.00010 \mathrm{~g} \mathrm{~cm}^{-2} \mathrm{ADD}^{-1}$, respectively. This behavior was different from the one with the highest fertilization dose, in which the Latina cultivar had the greatest NAR value $\left(0.00025 \mathrm{~g} \mathrm{~cm}^{-2} \mathrm{ADD}\right.$ ${ }^{1}$ ), followed by 'Guaneña' and 'Latina' (0.00020 and $\left.0.00017 \mathrm{~g} \mathrm{~cm}^{-2} \mathrm{ADD}^{-1}\right)$, respectively.

'Colombia' and 'Latina' reached minimum NAR values under similar conditions. 'Colombia' obtained a NAR value of $0.000027 \mathrm{~g} \mathrm{~cm}^{-2} \mathrm{ADD}^{-1}$ at $660.5 \mathrm{ADD}$ with the lowest fertilizer dose, reaching the same value at $694.35 \mathrm{ADD}$ with the highest dose. In the case of 'Latina', the maximum NAR values achieved are 0.00032 and $0.00017 \mathrm{~g} \mathrm{~cm}^{-2} \mathrm{ADD}^{-1}$ under low and high dose, respectively.

'Guaneña' behaved like 'Colombia' and 'Latina' with the highest dose, i.e., it reached its minimum NAR value at $711.25 \mathrm{ADD}\left(0.000026 \mathrm{~g} \mathrm{~cm}^{-2} \mathrm{ADD}^{-1}\right)$ and its maximum NAR value at $1,252 \mathrm{ADD}\left(0.00020 \mathrm{~g} \mathrm{~cm}^{-2}\right.$ $\left.\mathrm{ADD}^{-1}\right)$. However, at the lowest fertilization dose, the maximum NAR value $\left(0.000010 \mathrm{~g} \mathrm{~cm}^{-2} \mathrm{ADD}^{-1}\right)$ occurred at $255 \mathrm{ADD}$. The photosynthetic capacity decreased until the end of the cycle, when it reached the minimum NAR value $\left(0.000011 \mathrm{~g} \mathrm{~cm}^{-2} \mathrm{ADD}^{-1}\right)$. This behavior indicated that this cultivar defined production between 600 and 800 ADD. The falling NAR curve in the advanced stage of the crop indicated that the ability for photosynthesis was reduced.

The RGR results obtained in this study agree with Santos (2010), who reported that the highest RGR values were recorded in the early stages of the crop cycle, showing that the Colombia cultivar had the highest value, $0.85 \mathrm{~g} \mathrm{~g} \mathrm{~g}^{-1} \mathrm{~d}^{-1}$, followed by Guaneña $\left(0.27 \mathrm{~g} \mathrm{~g}^{-1} \mathrm{~d}^{-1}\right)$ and Latina $\left(0.12 \mathrm{~g} \mathrm{~g}^{-1} \mathrm{~d}^{-1}\right)$, in the experiment located at a lower height above sea level. The behavior of this variable decreased until the end of the cycle, reporting minimum values of $0.0048,0.017$, $0.013 \mathrm{~g} \mathrm{~g}^{-1} \mathrm{~d}^{-1}$ for 'Colombia', 'Latina', and 'Guaneña', respectively. Gaitán et al. (2013), in a growth analysis of Monserrate, Unica, and Morita cultivars, reported that the RGR in the three cultivars reached high values in the early stages of development and that, over time, these values decreased until the end of the cycle, reaching values equal to 0 when NAR was maximum, coinciding with the results obtained in this analysis.

De Oliveira et al. (2000) also recorded high RGR values in cultivar Aracy at the start of the cycle, with a gradual decrease. In this cultivar, the maximum values fluctuated between 0.15 and $0.25 \mathrm{~g} \mathrm{~g}^{-1} \mathrm{~d}^{-1}$. In the growth analysis of Russet Burbank cultivar by Lynch and Rowberry (1977), similar results were obtained. The RGR decreased over time, becoming minimal when NAR was at its maximum.

The behavior of the NAR was similar in all three cultivars. It had a progressive decrease until about $600 \mathrm{ADD}$ and continued its growth until the end of the cycle. The Guaneña cultivar had a decreased curve with the highest fertilization dose until 600 $\mathrm{ADD}$, with a slight increase up to $800 \mathrm{ADD}$ and a subsequent decrease. None of the cultivars reached negative NAR values. 'Latina' was the first to reach a value close to 0 , corresponding to $0.000033 \mathrm{~g} \mathrm{~cm}^{-2}$ $\mathrm{ADD}^{-1}$ at $643.66 \mathrm{ADD}$ with the lowest fertilizer dose and $0.000022 \mathrm{~g} \mathrm{~cm}^{-2} \mathrm{ADD}^{-1}$ at $660.50 \mathrm{ADD}$ with the highest fertilizer dose. In this case, the crop potential production was not defined in a certain period of the plant cycle.

Santos (2010) evaluated the same potato genotypes in two locations in Colombia. In both environments, in the initial stages of the crop cycle, values between 0.001 and $0.0014 \mathrm{~g} \mathrm{~cm}^{-2} \mathrm{~d}^{-1}$ were recorded. These values increased up to approximately half of the cycle at the low altitude location and descended at the end of the plant cycle. In the upper location, the increase and decrease in the NAR were not as evident as in the case of the other location. This behavior did not occur in this study because the agricultural and ecological characteristics under which the experiments occurred and were contrasted (Grime and Hunt, 1975), who argue that differences in the physiological behavior of the genotypes of the same species are determined by the geographical location of the experiments.

Meanwhile, in a study by De Oliveira et al. (2000), the Aracy cultivar had NAR values that were reduced over time, and, at the end of the cycle, when this cultivar started its senescence period, an increase occurred, as seen in this study, indicating that more photosynthetic activity and more biomass distribution and accumulation in tubers. This same behavior was presented by Nústez et al. (2009) and Segura et al. (2006) with Esmeralda and Betina cultivars.

Condori et al. (2008) showed that that Luki and Waycha cultivars were more efficient in photosynthetic terms, with NAR values between 4.39 and $6.65 \mathrm{~g} \mathrm{~cm}^{-2} \mathrm{~d}^{-1}$, with no differences from other tuber plants. Aguilar et al. (2006) found the highest NAR values in the early stages of the cultivation, 0.008 and $0.009 \mathrm{~g} \mathrm{~cm}^{-2}$ - week in Alpha and Milagros cultivars, respectively, which eventually decreased. 
Leaf area ratio, specific leaf area and fresh weight ratio

The LAR behavior in the three cultivars evaluated in this study was similar, recording values between 90 and $150 \mathrm{~cm}^{2} \mathrm{~g}^{-1}$ at the beginning of the crop cycle. The curve grew to a maximum value of $16 \mathrm{~cm}^{2} \mathrm{~g}^{-1} \mathrm{un}$ til $420 \mathrm{ADD}$ and, after that, decreased steadily until the end of the cycle. LAR, as shown in figure 9, was directly influenced by the FWR component because
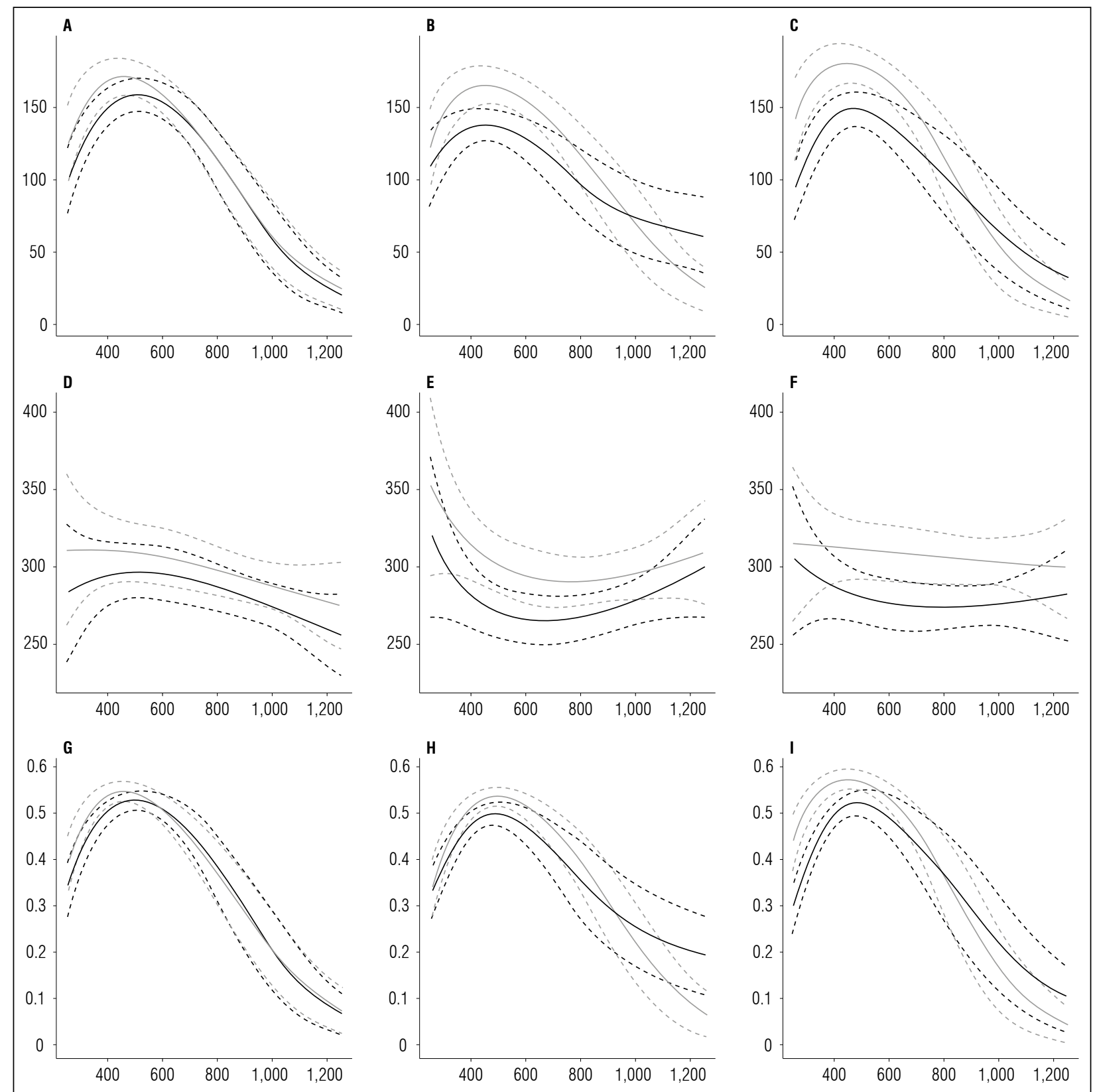

Figure 9. Leaf Area Ratio (LAR) and its components, Specific Leaf Area (SLA) and Fresh Weight Ratio (FWR) in potato cultivars (Solanum phureja Juz. et Buk.). The y-axis in figures A, B and C shows the LAR in $\mathbf{c m}^{2} \mathbf{g}^{-1}$, in figures D, E and F shows the SLA in $\mathrm{cm}^{2} \mathrm{~g}^{-1}$ and in figures $\mathrm{G}, \mathrm{H}$ and I shows the FWR in $\mathrm{g} \mathrm{g}^{-1}$. The $\mathrm{x}$-axis shows the thermal time in accumulated degree-days ADD. The black line indicates the dose of $260 \mathrm{~kg} \mathrm{ha}^{-1}$, and the gray line indicates the dose of $778 \mathrm{~kg} \mathrm{ha}^{-1}$. The dotted lines of each color indicate the Highest Posterior Density Intervals of 0.90. A, LAR 'Colombia'; B, LAR 'Guaneña'; C, LAR 'Latina'; D, SLA 'Colombia'; E, SLA 'Guaneña'. F, SLA 'Latina'; G, FWR 'Colombia'; H, FWR 'Guaneña'; I, FWR 'Latina'. 
their curves had the same tendency. This behavior indicated that the plants resort to significant changes in the distribution of dry matter through the organs to maintain LAR. The SLA slightly influenced the LAR behavior only in the Colombia cultivar, leading to the conclusion that, in addition to changes in the distribution of biomass to maintain LAR, the plants also resorts to small changes in the density of its leaves.

\section{CONCLUSION}

The Guaneña and Latina cultivars had better performance than the 'Colombia' cultivar, according to their physiological capacity to produce biomass and growth. This indicates that, without downplaying 'Colombia', which is the leading parental cultivar, the fact that they are improved from Colombia cultivar provides them added value, in terms of growth and productivity.

Conflict of interests: The manuscript was prepared and reviewed with the participation of the authors, who declare that there exists no conflict of interest that puts at risk the validity of the presented results.

\section{BIBLIOGRAPHIC REFERENCES}

Aguilar, M.G., J. Carrillo, A. Rivera, and V. González. 2006. Growth analysis and sink-source relationships in two potato (Solanum tuberosum L.) varieties. Rev. Fitot. Mex. 29(2), 145-156.

Borrego, F., M. Murillo, J. Fernández, A. López, V. Parga, and A. Carvajal. 2000. Nota Técnica. Anáisis de crecimiento en siete variedades de papa (Solanum tuberosum L.). Agron. Mesoam. 11(1), 145-149. Doi: 10.15517/ am.v11i1.17364

Cabezas, M. and G. Corchuelo. 2005. Estimación de la interceptación de la radiación solar en papa criolla (Solanum phureja Juz. et Buk.) en tres localidades colombianas. Agron. Colomb. 23(1), 62-73.

Condori, B., P. Mamani, R. Botello, F. Patiño, A. Devaux, and J.F. Ledent. 2008. Agrophysiological characterisation and parametrisation of Andean tubers: Potato (Solanum sp.), oca (Oxalis tuberosa), isaño (Tropaeolum tuberosum) and papalisa (Ullucus tuberosus). Eur. J. Agron. 28(4), 526-540. Doi: 10.1016/j.eja.2007.12.002

De Oliveira, A., J. Domingos, and S. Zambelo. 2000. Análise de crescimento na cultura da Batata submetida a diferentes lâminas de irrigação. Pesq. Agropec. Bras. 35(1986), 901-907. Doi: 10.1590/ S0100-204X2000000500006
Fourcaud, T., X. Zhang, A. Stokes, H. Lambers, and C. Körner. 2008. Plant growth modelling and applications: the increasing importance of plant architecture in growth models. Ann. Bot. 101(8), 1053-1063. Doi: 10.1093/aob/mcn050

Gaitán, Á., M. Gonzales, C. Ñústez, T.M. Saldaña-Villota, and J.M. Cotes-Torres. 2013. Growth and development functional analysis in four potato varieties (Solanum tuberosum subsp. andigena. Rev. Fac. Cienc. Básicas 9(2), 172-185. Doi: 10.18359/rfcb.344

Gardner, F., R. Pearce, and R. Mitchell. 1985. Physiology of crop plants. Iowa State University Press, Ames, IA.

Gelman, A. and J. Hill. 2007. Data analysis using regression and multilevel/hierarchical models. Cambridge University Press, New York, NY. Doi: 10.1017/ CBO9780511790942

Grime, J. and R. Hunt. 1975. Relative growth-rate: Its range and adaptive significance in a local flora. J. Ecol. 63(2), 393-422. Doi: 10.2307/2258728

Gutierrez, A.P.A.P. 1996. Applied population ecology: a supply-demand approach. John Wiley \& Sons, New York, NY.

Hadfield, J.D. 2010. MCMC Methods for multi-response generalized linear mixed models: The MCMCglmm R Package. J. Stat. Softw. 33(2), 1-22. Doi: 10.18637/jss. v033.i02

Hendrik, P. 1989. Plant growth analysis: towards a synthesis of the classical and the functional approach. Physiol. Plant. 75, 237-244.

Holdridge, L. 1967. Life zone ecology. Tropical Life Science, San Jose.

Huamán, Z. 1986. Systematic, botany and morphology of the potato. International Potato Center (CIP), Lima.

Hunt, R. 1982. Plant growth curves: The functional approach to plant growth analysis. Cambridge University Press, New York, NY.

Hunt, R. 2002. A modern tool for classical plant growth analysis. Ann. Bot. 90(4), 485-488. Doi: 10.1093/aob/ $\operatorname{mcf} 214$

Hunt, R. 2003. Growth analysis, individual plants. Elsevier, Sheffield, UK.

Kutschera, U. 2019. Cell expansion in plant development. Braz. J. Plant Physiol. 12(1), 65-95.

Lambers, H., F.S. Chapin, and T. Pons. 1998. Plant physiological ecology. $2^{\text {nd }}$ ed. Springer. Doi: 10.1007/978-1-4757-2855-2

Larcher, W. 2003. Physiological plant ecology. Ecophysiology and stress physiology of the functional groups. Springer-Verlag Berlin, Heidelberg, New York.

Lynch, D.R. and R.G. Rowberry. 1977. Population density studies with Russet Burbank II. The effect of fertilization and plant density on growth, development 
and yield. Am. Potato J. 54, 57-71. Doi: 10.1007/ BF02851874

Machida-Hirano, R. 2015. Diversity of potato genetic resources. Breed. Sci. 65(1), 26-40. Doi: 10.1270/ jsbbs. 65.26

Manetsch, T.J. 1976. Time-Varying distributed delays and their use in aggregative models of large systems. IEEE Trans. Syst. Man Cybern. Syst. 6(8), 547-553. Doi: 10.1109/TSMC.1976.4309549

Marenco, R.A. and N. Fernandes Lopes. 2009. Fisiologia vegetal. UFV, Viçosa, Brazil.

Montoya, F., D. Camargo, J.F. Ortega, J.I. Córcoles, and A. Domínguez. 2016. Evaluation of Aquacrop model for a potato crop under different irrigation conditions. Agric. Water Manage. 164, 267-280. Doi: 10.1016/j. agwat.2015.10.019

Ñústez, C., M. Santos, and M. Segura. 2009. Dry matter allocation and partitioning of four potato varieties (Solanum tuberosum L.) in Zipaquirá, Cundinamarca (Colombia). Rev. Fac. Nac. Agron. Medellin 62(1), 4823-4834.

Oliveira, J.S., H.E. Brown, A. Gash, and D.J. Moot. 2016. An explanation of yield differences in three potato cultivars. Agron. J. 108(4), 1434-1446. Doi: 10.2134/ agronj2015.0486

Ovchinnikova, A., E. Krylova, T. Gavrilenko, T. Smekalova, M. Zhuk, S. Knapp, and D.M. Spooner. 2011. Taxonomy of cultivated potatoes (Solanum section Petota: Solanaceae). Bot. J. Linn. Soc. 165(2), 107-155. Doi: 10.1111/j.1095-8339.2010.01107.x

Plummer, M., N. Best, K. Cowles, and K. Vines. 2006. CODA: Convergence diagnosis and output analysis for MCMC. R News 6(1), 7-11.

R Core Team, 2020. R: A language and environment for statistical computing. R Foundation for Statistical Computing, Cary, NC.

Rodríguez, D., J.M. Cotes, and J.R. Cure. 2012. Comparison of eight degree-days estimation methods in four agroecological regions in Colombia. Bragantia 71(2), 299-307. Doi: 10.1590/S0006-87052012005000011
Rodríguez, D., J.R. Cure, J.M. Cotes, A.P. Gutierrez, and F. Cantor. 2011. A coffee agroecosystem model: I. Growth and development of the coffee plant. Ecol. Model. 222(19), 3626-3639. Doi: 10.1016/j. ecolmodel.2011.08.003

Santos, M. 2010. Evaluación del crecimiento, desarrollo y componentes de rendimiento de cuatro cultivares de papa criolla en dos localidades del departamento de Cundinamarca. Universidad Nacional de Colombia, Bogotá.

Searle, S., G. Casella, and C.E. McCulloch. 1992. Variance components. Jhon Wiley \& Sons, New York, USA. Doi: $10.1002 / 9780470316856$

Segura, M., M. Santos, and C. Núustez. 2006. Desarrollo fenológico de cuatro variedades de papa (Solanum tuberosum L.) en el Municipio de Zipaquirá (Cundinamarca). Fitot. Colomb. 6(2), 33-43.

Sorensen, D. and D. Gianola. 2002. Likelihood, bayesian, and MCMC methods in quantitative genetics. Springer, Statistics for Biology and Health. Doi: 10.1007/ b98952

Struik, P.C. 2007. Responses of the potato plant to temperature. pp. 367-393. In: Vreugdenhil, D. (ed.), Potato biology and biotechnology. Elsevier, Wageningen, The Netherlands. Doi: 10.1016/B978-0-444-51018-1. X5040-4

Taiz, L., E. Zeiger, I. Moller, and A. Murphy. 2014. Plant physiology and development. $6^{\text {th }}$ ed. Sinauer Associates, Los Angeles, CA.

Tekalign, T. and P.S. Hammes. 2005. Growth and productivity of potato as influenced by cultivar and reproductive growth. I. Stomatal cnductance, rate of transpiration, net photosynthesis, and dry matter production and allocation. Sci. Hortic. 105(1), 13-27. Doi: 10.1016/j.scienta.2005.01.029

Vansickle, J. 1977. Attrition in distributed delay models. IEEE Trans. Syst. Man Cybern. Syst. 7(9), 635-638. Doi: 10.1109/TSMC.1977.4309800

Wood, P. 1967. Algebraic model of the lactation curve in cattle. Nature 216, 164-165. Doi: 10.1038/216164a0 